\title{
MAKNA GERAK DAN FUNGSI TARI TAJUN TANDANG \\ DALAM UPACARA BATATUNGKAL DI KABUPATEN TANAH LAUT \\ KALIMATAN SELATAN
}

\author{
Aprina Sentia Dewi \\ Universitas Negeri Surabaya \\ Email: aprina.18017@mhs.unesa.ac.id
}

\begin{abstract}
Abstrak
Penyajian tari Tajun Tandang diawal upacara dimaksudkan sebagai tanda penyambutan nenek moyang. Selain itu juga sebagai simbol ungkapan suka ria masyarakat biaju terhadap nenek moyang yang berkenan hadir ditengah-tengah pelaksanaan upacara Fungsi tari dikelompokkan sebagai berikur fungsi tari sebagai keindahan, hiburan dan sebagai sarana upacara. Dilihat dari sejarahnya tari tajung ini memiliki fungsi sebagai hiburan dan sarana upacara pengobatan orang sakit yang disebut batatungkal.Ragam gerak dalam Tari Tajun Tandang ini memiliki 9 ragam Gerakan tersebut bersifat sederhana dalam kehidupan sehari-hari dengan menirukan kegiatan dan emosi manusia.Tujuan dari penelitian ini digunakan untuk mendeskripsikan secara luas dan mendalam untuk mendapatkan data dengan menggunakan kualalitatif deskripsi dan informasi. Teknik pengumpulan data dalam penelitian ini dengan observasi analisis data berupa wawancara dan dokumentasi.
\end{abstract}

Kata Kunci: makna, fungsi,tari tajun tandang

\section{THE MEANING OF MOVEMENT AND THE FUNCTION OF DANJUN TANDANG IN BATATUNGKAL CEREMONY IN TANAH LAUT DISTRICT, KALIMATAN SELATAN}

\begin{abstract}
The presentation of the Tajun Tandang dance at the beginning of the ceremony was intended as a sign of welcoming the ancestors. In addition, it is also a symbol of the joyful expression of the biaju community for the ancestors who were willing to be present in the middle of the ceremony. The function of dance is grouped as a berikur dance function as beauty, entertainment and as a means of ceremony. Judging from its history this tajung dance has a function as entertainment and a means of treating the sick called batatungkal. The various movements in the Tajun Tandang Dance have 9 types of movements that are simple in daily life by imitating human activities and emotions. The purpose of this study used to describe broadly and deeply to obtain data using qualitative descriptions and information. Data collection techniques in this study employ observation of data analysis in the form of interviews and documentation.
\end{abstract}

Keywords: meaning, function, dance

\section{PENDAHULUAN}

Dalam tata kehidupan masyarakat kita dari zaman lampau sampai sekarang, masih tetap tidak lepas dari kegiatan-kegiatan yang berhubungan dengan adanya pelaksanaan upacara dan tari didalamnya turut berperan sebagai salah satu media pokoknya. Upacaraupacara yang mempergunakan tari sebagai salah 
satu medianya ada 2 macam, yaitu: upacara yang bersifat keagamaan dan upacara adat yang sesuai dengan tradisi daerah setempat(Rusliana, 1982:72). Bentuk-bentuk sebuah tradisi suatu masyarakat pada umumnya akan berkembang dan berubah oleh karena keinginan masyarakat pendukungnya. Perubahan-perubahan yang terjadi disebabkan oleh sebagai faktor, baik yang bersifat internal maupun eksternal. Warisan berupa kebiasaan-kebiasaan dari generasi pendahulu kita, merupakan kesadaran yang didasari oleh pemikiran-pemikiran bersama untuk menciptakan kehidupan yang lebih baik.

Kebudayaan merupakan daya cipta bebas yang memiliki tujuh unsur di dalamnya. Salah satu unsurkebudayaan tersebutadalah kesenian. Kesenian merupakan salah satu bagian yang dibutuhkan manusia dalam kehidupan. Melalui kesenian manusia dapat mengekspresikan pengalaman pribadi yang indah atau pengalaman estetis. Bentuk ekspresi tersebut sebagai pengalaman pribadi dapat berupa gerak, tulisan dan sebagainya. Pada dasarnya kesenian dalam masyarakat di pandang sebagai salah satu unsur kebudayaan. Secara umum orang sering menyatakan bahwa kesenian merupakan ekspresi jiwa manusia tentang keindahan. Sebenarnya tidak semua karya seni dapat dikatakan demikian karena ada karya seni yang lebih mengutamakan pesan budaya yang mengandung nilai budaya dari masyarakat pendukungnya. Hal ini berarti masyarakat yang bersangkutan bermaksud menjawab atau menginterprestasikan permasalahan kehidupan sosialnya yang mendambakan kemakmuran, kebahagian, rasa aman, rasa kecewa, dan sedih, melalui bentuk karya seni. Dengan demikian karya seni itu sendiri mempunyai berbagai makna yang tersirat di belakang objek yang seringkali bersifat simbolis. Sehubungan dengan hal itu, terdapat beberapa fungsi kesenian bagi masyarakat pendukungnya, antara lain sebagai: media pendidikan, media ekspresi jiwa manusia, dan sebagai hiburan. Kesenian sebagai hasil ekspresi keindahan yang mengandung pesan budaya bisa terwujud dalam bermacam-macam bentuk seperti seni tari, seni musik, seni karawitan, seni pedalangan, seni teater, seni sastra, film, dan seni rupa. Kalimantan Selatan memiliki kebudayaan yang beraneka ragam. Budaya yang beraneka ragam tersebut merupakan kekayaan yang perlu dilestarikan dan dikembangkan terus-menerus guna meningkatkan ketahanan budaya dan dapat dimanfaatkan untuk menunjang wisata budaya.

Kalimantan Selatan secara dominan di diami oleh Suku Banjar yang secara khas dikenal pula dengan sebutan Urang Banjar Pahuluan, Urang Banjar Batang Banyu, dan Urang Banjar Kuala. Adapun berbagai macam Suku yang mendiami pulau ini, seperti Suku Dayak Bukit, Suku Dayak Ngaju, Suku Dayak Maanyan, Suku Jawa, Suku Madura dan Suku Bugis. Selain itu terdapat pula masyarakat keturunan Cina, Arab, India, Pakistan, dan sebagainya yang tersebar di semua wilayah Propinsi Kalimantan Selatan. Tari tradisional merupakan karya seni warisan nenek moyang pada masa lalu yang berbentuk sederhana dan banyak dipengaruhi oleh kepercayaan dinamisme dan animisme. Oleh sebab itu, sejak zaman dahulu tarian sudah memiliki fungsi yang sentral dalam kehidupan beragama. Peran tari dalam upacara terkait dengan cara dan tujuan suatu upacara keagamaan atau ritual. Seni tari mewariskan bentuk-bentuk tradisi dan non tradisi. Dalam perkembangannya seni tari tradisional akhirnya mewariskan seni pertunjukan yang baru dan inovatif melalui dramatari dan sendratari. Salah satu dari pada kesenian tari tradisional adalah Tari Tajun Tandang.

Dari berbagai bentuk tari pedalaman yang ada di Kabupaten Tanah Laut, di antara tari pedalaman tersebut adalah Tari Tajun Tandang. Sekilas tentang Tari Tajun Tandang Suku Dayak Ngaju.Tari Tajun Tandang berfungsi sebagai tari bersifat upacara dan hiburan, mengandung nilai-nilai filosofis yaitu upacara adat. Tari pengobatan yang menggambarkan aktifitas kehidupan Suku Dayak Ngaju yang menurut kepercayaan yang berkembang bagi Suku Dayak Ngaju desa Tanjung Bajuin apabila salah seorang warga mengalami sakit 
sampai berbulan-bulan tidak juga sembuh, semua ini disebabkan oleh karena kemarahan larangan para leluhur mereka, dan konon penyebabnya dikarenakan adanya sesuatu yang menjadi larangan atau pantangan di langgar/ dilakukan baik disengaja maupun tidak di sengaja, sakit warga itu semata-mata karena adanya semacam gangguan dari roh-roh gaib para nenek moyang Suku Dayak Ngaju atau bisa juga disebabkan suatu kewajiban seperti penyelenggaraan upacara-upacara adat yang terabaikan oleh warga Suku pedalaman ini, padahal itu semua merupakan suatu kewajiban yang harus dilaksanakan. Guna mengatasi hal tersebut perlulah kiranya dilaksanakan Upacara Adat "Batatungkal.

\section{METODE}

Tujuan dari penelitian ini digunakan untuk mendeskripsikan secara luas dan mendalam untuk mendapatkan data dan informasi tentang fungsi tari dan makna tari Tajun Tandang di desa bajuin Tanah Laut Kalimatan Selatan. Lokasi dilakukannya penelitian ini adalah didesa bajuin Tanah Laut Kalimatan Selatan. Teknik pengumpulan data dalam penelitian ini dengan observasi, wawancara dan dokumentasi untuk mengetahui fungsi tari dan makna tari.

Analisa data merupakan upaya mencari dan menanta secara sistematis catatan dari hasil wawancara, observasi, dan dokumentasi, untuk meningkatkan pemahaman peniliti tentang temuan-temuanyangberdasarkanpermasalahan yang diteliti. analisis data merupakan proses mengatur urutan data, mengorganisasikan kedalam suatu pola, kategori dan satuan urutan dasar. Pada penelitian Analisa data ini yang di peroleh dilapangan menggunakan tahapantahapn seperti dikemukakan oleh miles dan Huberman sebagaimana dalam (Sugiyono 2008 :246 - 247) yaitu melalui pengumpulan data dilakukan melalui wawancara langsung dengan informan, pengamatan dan penggunaan dokumentasi sekunder maka dilakukan Analisa

1. Reduksi data merupakan proses pemilihan, pemusatan perhatian pada penyerdehanaan, pengabstrasian dan transpormasi data kasar yang muncul dari catatan-catatan tertulis dilapangan reduksi data berlangsung secara terus menerus selama penilitian berlangsung.

2. Penyajian data merupakan penelitian yang dilakukan dalam bentuk teks naratif dalam bentuk kata-kata atau kalimat.

3. Penarikan kesimpulan dan vertifikasi penarikan kesimpulan merupakan langkah terakhir dari proses penelitian kualitatif yaitu melakukan penarikan kesimpulan atas dasar hasil analisis dan interpretasi data.

Pendekatan yang digunakan dalam penelitian ini adalah pendekataan kualitatif tujuan menggunakan pendekatan kualitatif ini adalah untuk memperoleh deskripsi tentang fungsi tari dan makna gerak tari tradisional Tari Tajun Tandang desa Bajuin Kabupaten Tanah Laut Kalimatan Selatan. Penelitian kualitatif adalah penelitian yang bermasud memahami fenomena tentang yang alami oleh subjek penelitian dengan cara deskriptif dalam bentuk kata-kata dan Bahasa, pada suatu konteks yang khusus yang alamiah dan memanfaatkan berbagai metode alamiah (Moleong 2011: 6).

Selanjutnya penelitian ini menggunakan jenis penelitian deskritif adalah penelitian yang dilakukan untuk menggambar dan mejelaskan secara sistematik, factual, dan akurat mengenai fakta dan sifat populasi tertentu.

\section{HASIL DAN PEMBAHASAN \\ Hasil \\ Fungsi tari Tajun Tandang}

Di dalam setiap pertunjukkan atau penampilan tari selalu ada unsur kegunaan , nilai guna atau fungsi dari tarian tersebut. Keberadaan seni tari dengan lingkungannya, benar-benar merupakan masalah sosial yang cukup menarik. Fungsi tari dikelompokkan sebagai berikur fungsi tari sebagai keindahan, hiburan dan sebagai sarana upacara. Dilihat dari sejarahnya tari tajung ini memiliki fungsi sebagai hiburan dan sarana upacara pengobatan orang sakit yang disebut batatungkal. Tari Tajun Tandang dalam kehidupan masyarakat dayak biaju menyandang fungsi sebagai sarana 
upacara ritual dan hiburan Penyajian tari Tajun Tandang ini sebagai bagian dari upacara batatungkal memiliki dan berkaitan dengan perhitungan upacara memiliki keterkaitan dengan perhitungan hari dan waktu untuk menentukkan pelaksanaan upacara.

Penyajian tari Tajun Tandang diawal upacara dimaksudkan sebagai tanda penyambutan nenek moyang. Selain itu juga sebagai simbol ungkapan suka ria masyarakat biaju terhadap nenek moyang yang berkenan hadir ditengah-tengah pelaksanaan upacara Penyajian tari Tajung Tandang biasanya dimulai sekitar pukul 9 malam setelah balian membakar kemenyannya dan membacakan mantra. Masyakarakat percaya bahwa pada saat tengah malam hari roh-roh gaib mudah dipanggil untuk menghadiri pelaksaanaan upacara. Dengan demikian penentuan waktu ini membuktijan bahwa penyajian tari tajun tandang di perhitungkan dalam keberhasilan pelaksanaannya karena sesuai dengan pijakan tata cara upacara masyarakat Dayak. Tari Tajun Tandang selain sebagai sarana ritual tari ini juga memiliki fungsi sebagai sarana hiburan dan pengikat solidaritas masyarakat. Manakala tari disajikan sebagai sarana hiburan maka tarian ini didapat memberikan ruang bagi para pelaku upacara atau pihak yang terlibat untuk bersuka ria, saling mehibur diri baik dengan menari bersama, ataupun hanya dengan menyaksikan saja. Hadirnya suasana suka cita seperti ini dapat menghibur setiap orang sebagai bagian pelepas dari ketegangan-ketegangan dalam aktivitas sehari-hari termaksuk dalam upacara batatungkal.

\section{Makna gerak Tari Tajun Tandang}

Bentuk penyajian Kehadiran tari di depan penonton bukan hanya menghadirkan dan menampilkan serangkaiaan gerak akan tetapi rapi dan indah atau unsur-unsur yang dapat mendukung penampilan dari sebuah karya tersebut.sebuah penampilan suatu karya tari dengan bentuk penyajian yang indah dan menarik akan mendapat perhatian dan daya Tarik pesona bagi siapapun yang sedang menikmati sebuah tarian tersebut, bentukk penyajian adalah suatu yang dipertontonkan atau diperagakan baik secara langsung oleh media atau individu / kelompok dalam suatu pertunjukan. Gerak di dalam tari bukan lah gerak yang realitis, tetapi gerak yang telah diberi untuk ekpresif dan estetis.

Gerak tari selalu melibatkan anggota tubuh manusia. Menurut dibia dkk. (2006: 146) gerak tari merupakan unsur utama dari tari. Ketika menyaksikan suatu pertunjukkan tari kita akan melihat berbagai macam warna dan corak gerak. Kita bias mengindetifikasi dari sisi jenis geraknya, keseharian, ketangkasan, gerak stilasi dan gerak yang abstrak.

Makna Tari Tajun Tandang makna adalah bagian yang tidak terpisahkan dan selalu melakukan dari apa saja yang kita tuturkan, pengertian makna sendiri sangat beragam makna merupakan arti atau maksud penting gerak dalam tari yang mengandung watak tertentu, jelasnya setiap gerakan yang di ungkapkan oleh penari menimbulkan kesan tertentu kepada penontonnya baik itu gerak yang kaku maupun gerak yang telah distilasi (Soedarsono 1986: 99) menyatakan bahwa gerak distilasi merupakan gerak wantah menjadi gerak yang tidak wantah, baik gerak itu di perhalus maupun di rombak dari gerak biasanya. Tari bukan hanya sekedar gerakgerakan bermakna yang indah. Makna gerak tari suatu daya yang membuat gerakan itu hidup. Penjiwaan dalam tari, tidak mesti harus ada seperti gambaran ceritannya, melainkan hanya dalam rasa geraknya, penyaluran rasa yang dapat di gerakan melalui gerakan itu sendiri.

Berdasarkan makna gerak tari, untuk mengungkapkan makna dalam tari ada dua bagian yang mengandung penggambaran bagian yang mengandung penggambaran gerak, yaitu gerak abstrak dan gerak yaitu gerak representatif (Sumaryono dan Suanda 2006: 82) gerak abstrak adalah gerak yang semata-mata yang menekankan pada kualitas geraknya itu sendiri, dari biasanya gerak abstrak adalah gerak yang semata-mata yang menekankan pada kualitas gerak itu sendiri, dan biasanya gerak abstrak disebut dengan 
murni, sedangkan gerakan representatif adalah gerakan yang menggambarkan suatu benda atau suatu perilaku manusia maupun binatang, gerak representatif biasanya disebut juga dengan gerak maknawi karena secara langsung menunjukkan arti dan makna.

Tari sebagai fungsi tari dalam setiap pertunjukkan banyak berkembang dikalangan masyarakatyang ada di dalam tatakehidupannya masih mengacu pada nilai-nilai budaya agraris serta masyarakat yang memeluk agama yang dalam kegiatan ibadahnya sangat melibatkan seni pertunjukkan. Tari ritual biasanya berkembang dimasyarakat yang primitif sesuai dengan kepercayaan budaya primitif, kegiatan tari yang masih sangat sederhana itu sebagian besar didasari dari ungkapan ekpresi manusia yang sering dihubungkan dengan pemujaan atau cara berkomunikasi dengan dewa maupun, penguasa, penyembahan nenek moyang. Ketika tari diadakan untuk kepentingan upacara atau ritual adat yang disakralkan oleh masyrakat setempat, sebagian sajian kepada tuhan diatas (tuhan dan leluhur) sajian ini juga berfungsi sebagai seni yang sakral dan religius.dapat disimpulkan kegiatan ritual dan konsep pada suatu kebudayaan tertentu. Nilai dan konsep tersebut adalah yang mendasari mengatur, dan mengikat kegiatan tari yang bersifat ritual tersebit, baik itu cara bergerak, desain dan bentuk pertunjukkan. Semua itu merupakan suatu kesatuan dalam unsur-unsur budaya setempat yang telah dibangun dan terorganisasi oleh orang-orang adat. Fungsi tari sebagai upacara dapat ditelusuri pada masyarakat primitif yang berkebudayaan purba dengan kepercayaan animisme (roh-roh gaib), dinasmisme (benda-benda yang memiliki kekuataan) dan toteisme (binatang yang dapat mempengaruhi kehidupan). dalam pelaksanaan upacara itulah kesenian peran penting dalam pelaksanaan upacara sebagai sarana untuk mehadirkan daya magis atau kekhidmatan upacara. Dalam kepercayaan itu selalu dipelihara dan dilindungi secara turun menurun demi suatu keselamatan hidupnya dengan cara mengadakan upacara untuk menjalin hubungan dewa-dewa atau roh-roh leluhurnya.
Ragam gerak dalam Tari Tajun Tandang ini memiliki 9 ragam diantaranya bintang menyala, igal, igong, sampurak hulu, ulak danum, sambangan bowo, saluang mudik, angin tutus, balahindang dan step 4. Gerakan tersebut bersifat sederhana dalam kehidupan sehari-hari dengan menirukan kegiatan dan emosi manusia. Dalam ragam gerak Tari Tajun Tandang ini di ambil dari kejadian masyarakat bajuin suku dayak biaju sebagai media ritual dan pengobatan untuk menyembuhkan orang sakit yang cukup lama yang diganggu oleh kemarahan roh-roh leluhur yang disebut kesurupan dengan mengadakan upacara yang disebut upacara batatatungkal.

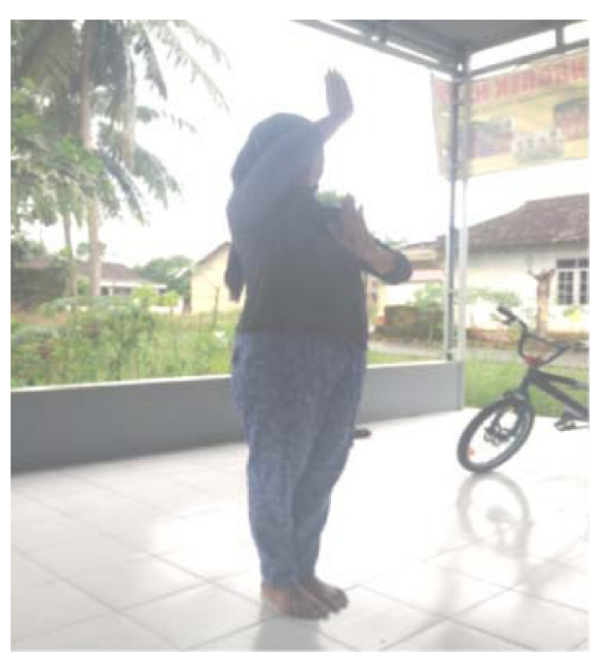

1. Gerakan Bintang Menyala ini mengandung dan makna nilai religius. Dalam gerakan ini melambangkan upacaraakansegeradimulai dan dalam gerakan bintang menyala ini ialah sebelum memulai upacara hendaknya memohon kepada sang pencipta sekaligus upaya untuk menenggakkan ketuhanan agar dimudahkan dengan segala urusan dan memohon agar upacara pengobatan (batatungkal) berjalan denganlancarsampai akhir. Ragam gerak Bintang Menyala juga memiliki nilai pendidikan, dimana pada ragam gerak ini menggambarkan manusia di ajarkan apapun yang ingin kita lakukan hendaknya dimulai dengan berdoa.Selain itu, mendidik kepada generasi penerus supaya memiliki ikatan, adat istiadat,tata cara mengerjakan sesuatu 


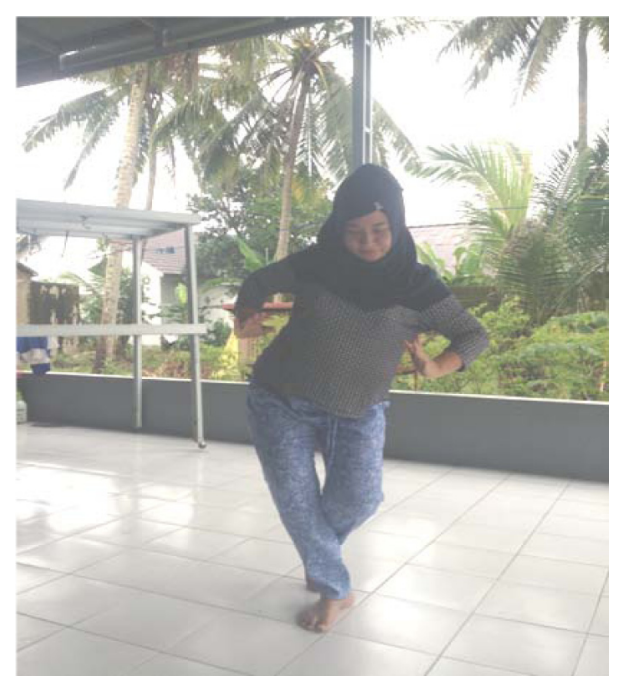

2. Igal Igong yang artinya kekuataan. Makna dalam gerakan Igal Igong mengandung nilai religius yang menggambarkan komunikasi manusia dengan yang gaib percaya untuk untuk menyampaikan tujuan yang diinginkan yaitu melalui persembahan pertama dengan mengunakan janur untuk memanggil ro-roh (leluhur).Pada ragam gerak Igal Igong memiliki nilai pendidikan yang dapat diajarkan kepada keturunan atau generasi penerus kita bahwa di dunia ini ada akan hal yang gaib. Kita dapat mengajarkan kepada keturunan atau generasi penerus kita bahwa wajib bagi kita mempercayai hal-hal yang seperti itu, dimana kita saling menghargai dan tidak mengganggu satu sama lain.

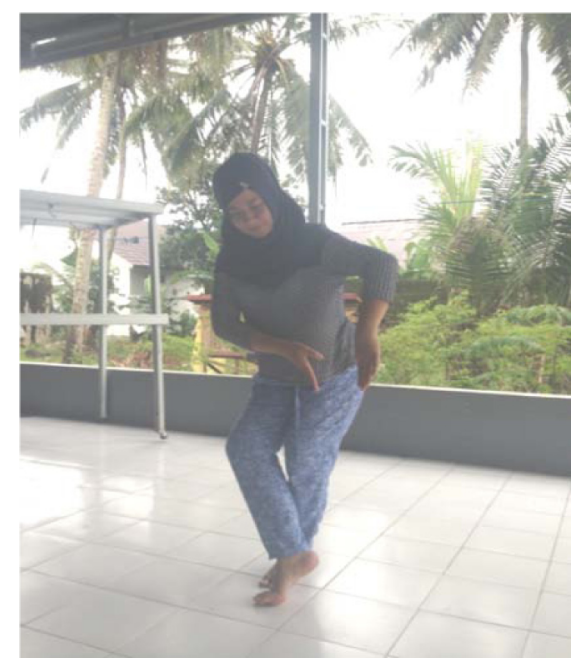

3. Ragam gerak Sampurak Hulu ini mengandung makna melalui cara hidup bersaudara, kerukunan, dan kekeluargaan juga bermusyawarah dan masyarakat dayak biaju menampilkan relasi antar manusia dan manusia. Dalam ragam gerak Sampurak Hulu ini masyarakat dayak ngaju berkumpul, dan akan melaksanakan upacara. Dalam ragam gerak Sampurak Hulu memiliki nilai pendidikan dimana dapat diajarkan bahwa jika kita ingin melakukan suatu hal yang besar salah satunya adalah melestarikan seni budaya masyarakat setempat kita tidak bisa sendiri, karena pada dasarnya kita merupakan makhluk sosial dimana antar sesama manusia kita harus berinteraksi.

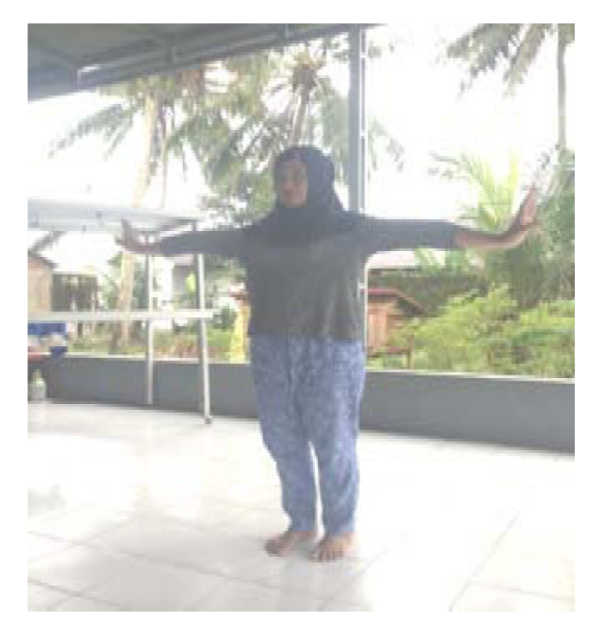

4. Makna dalam ragam gerak Ulak Danum ini mengandung nilai religius dan adanya hubungan seluruh manusia dengan seluruh ciptaan tuhan pada alam semesta. Hubungan ini manusia dengan yang gaib bagi masyarakat dayak ngaju dalam hubungan ini menjadi prioritas dalam seluruh perilaku kehidupan. Dalam gerakan ulak danum ini menggambar akan pemanggilan roh-roh nenek moyang (leluhur).Sama halnya seperti ragam gerak Igal Igong ragam gerak Ulak Danum memiliki nilai pendidikan yang dapat diajarkan kepada keturunan atau generasi penerus kita bahwa di dunia ini ada akan hal yang gaib. Kita dapat mengajarkan kepada keturunan atau 
generasi penerus kita bahwa wajib bagi kita mempercayai hal-hal yang seperti itu, dimana kita saling menghargai dan tidak mengganggu satu sama lain.

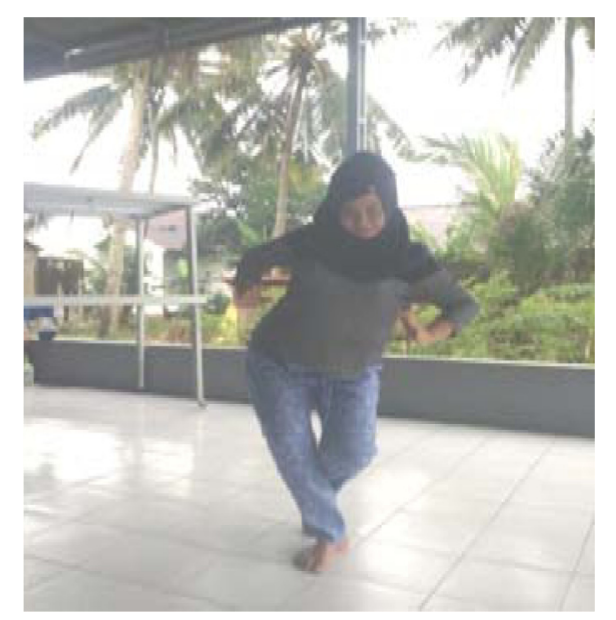

5. Sambangan Bowo merupakan ragam gerak yang memiliki makna nilai sosial yang menggambarkan masyarakat bajuin suku dayak biaju bekumpul untuk mengusir rohroh leluhur yang mengganggu di daerah nya agar terhindar dari gangguan-gangguan gaib juga sebagai tolak bala, dimana kita sebagai manusia yang hidup di alam nyata dan diberi kehidupan yang seutuhnya oleh sang maha pencipta harus bisa melindungi diri dari hal-hal yang ingin mencelakai dan mengganggu kehidupan kita.

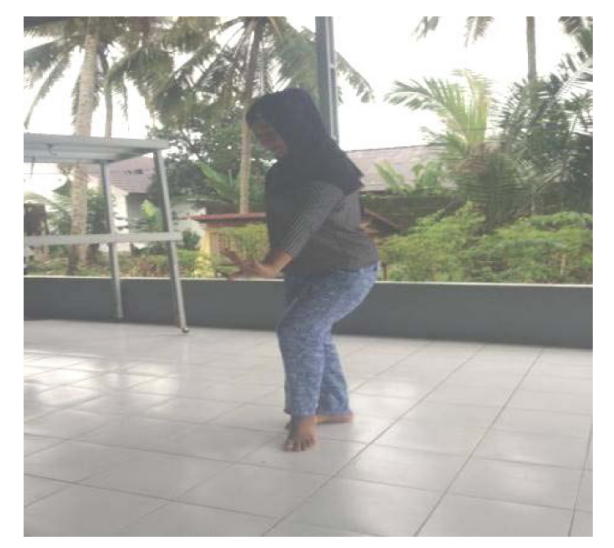

6. Saluang mudik merupakan ragam gerak yang menggambarkan masyarakat yang ingin memberikan persembahan buat roh leluhur melalui sang dukun. Nilai dalam gerakan ini memiliki nilai religius yang selalu berhubungan dan kepercayaan yang diberikan kepada tetuha adat atau dukun untuk memimpin upacara batatukal tersebut.

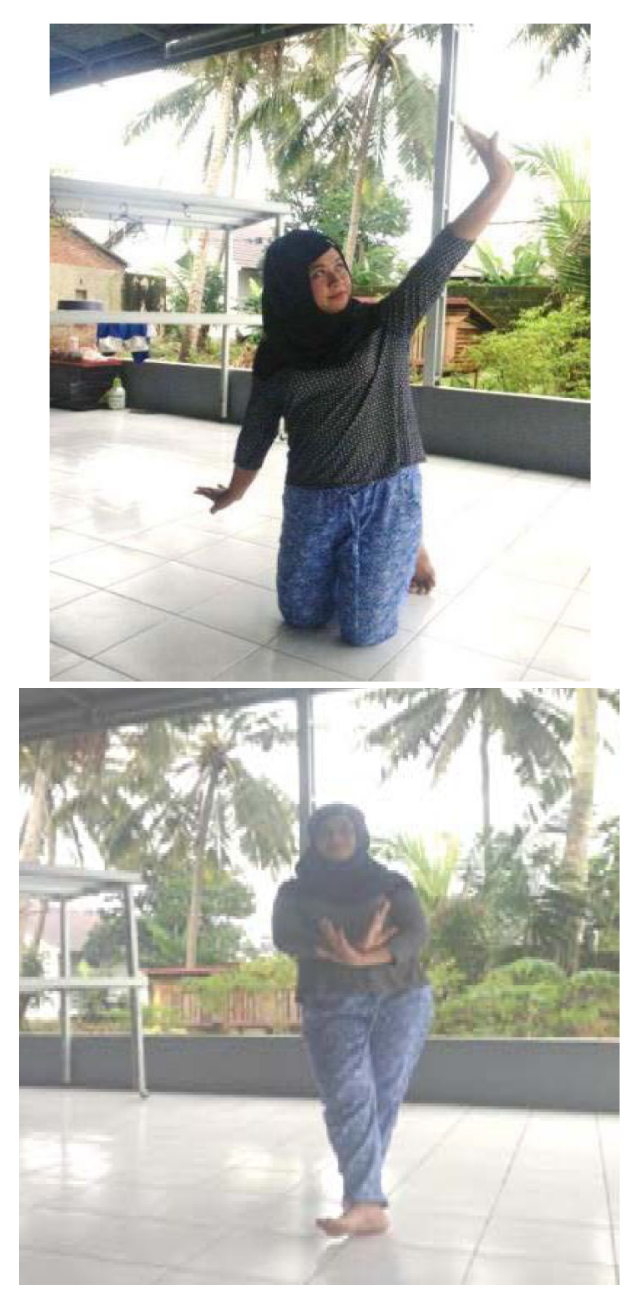

7. Pada ragamgerak Angin Tutus menceritakan tentang seorang pawang, atau dukun mengobati seseorang yang sedang sakit. Dengan gerakan inprofisasi tetapi tetap dalam aturan aturan tari yang indah, ragam Angin Tutus ini adalah gerakan dimana beberapa penari mengalami kesurupan dan seorang pawang berusaha menyembuhkannya. Dalam gerakan Angin Tutus memiliki nilai estetika yang tinggi dimana dengan ekpresi gerakan tubuh yang bebas tetapi tetap mementingkan 
keindahan gerak dan rasa yang kuat dengan menikmati keindahan gerak. Gerakan ini menggambarkan dukun mengobati yang sedang sakit dengan menggunakan darah ayam hitam sebagai tapung tawar untuk mehindari dan mebuang penyakit yang diganggu oleh roh-roh (leluhur) nenek moyang.

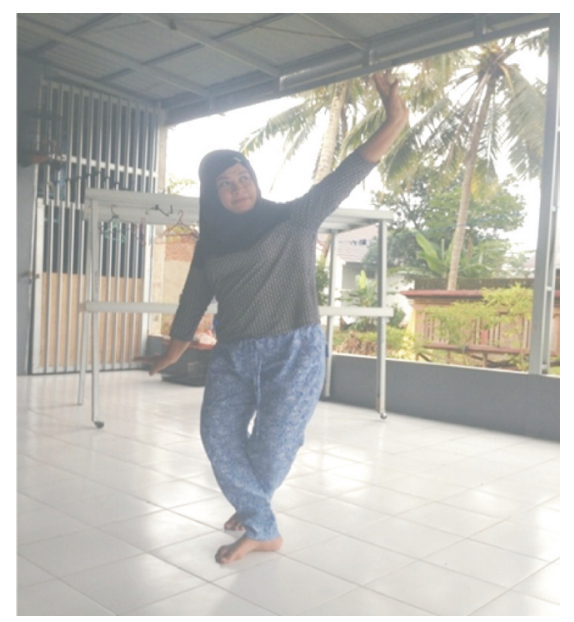

8. Dalamgerakanbalahidanginimegambarkan gadis yang diobati telah sembuh dan masyarakat bajuin suku dayak biaju menyambut dengan gembira.Ini merupakan salah satu ragam gerak yang memiliki nilai sosial karena adanya terbentuknya kekompakan dan kerukunanan masyarakat bajuin suku dayak biaju.

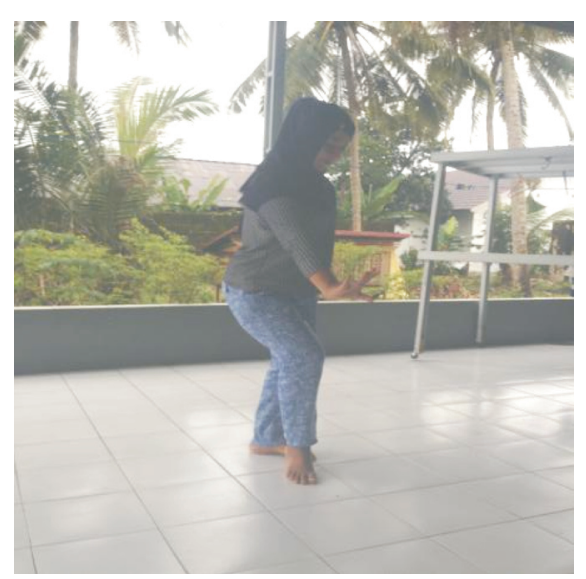

9. Ragam gerak step 4 Gerakan ini merupakan makna nilai estetika, karena di dalam gerakan step 4 ini memilki makna kehidupan yang mengisahkan tentang kehidupan yang baik dan benar. Dan di dalam gerakan ini menggambarkan Sang dukun menjaga orang yang sakit tersebut tidak akan mengalami kesurupan lagi.

\section{KESIMPULAN}

Berdasarkan hasil penelitian tentang makna dan fungsi dalam tari tajung tandang penelitian ini menggunakan pendekataan kualitatif. Tari Tajun Tandang dalam kehidupan masyarakat dayak biaju menyandang fungsi sebagai sarana upacara ritual dan hiburan Penyajian tari Tajun Tandang ini sebagai bagian dari upacara batatungkal memiliki dan berkaitan dengan perhitungan upacara memiliki keterkaitan dengan perhitungan hari dan waktu untuk menentukkan pelaksanaan upacara. Penyajian tari Tajun Tandang diawal upacara dimaksudkan sebagai tanda penyambutan nenek moyang. Selain itu juga sebagai simbol ungkapan suka ria masyarakat biaju terhadap nenek moyang yang berkenan hadir ditengah-tengah pelaksanaan upacara Penyajian tari Tajung Tandang biasanya dimulai sekitar pukul 9 malam setelah balian membakar kemenyannya dan membacakan mantra.

Makna Tari Tajun Tandang makna adalah bagian yang tidak terpisahkan dan selalu melakukan dari apa saja yang kita tuturkan, pengertian makna sendiri sangat beragam makna merupakan arti atau maksud penting gerak dalam tari yang mengandung watak tertentu, jelasnya setiap gerakan yang di ungkapkan oleh penari menimbulkan kesan tertentu kepada penontonnya Ragam gerak dalam Tari Tajun Tandang ini memiliki 9 ragam diantaranya bintang menyala, igal, igong, sampurak hulu, ulak danum, sambangan bowo, saluang mudik, angin tutus, balahindang dan step 4. Gerakan tersebut bersifat sederhana dalam kehidupan sehari-hari dengan menirukan kegiatan dan emosi manusia.

\section{DAFTAR PUSTAKA}

Ahmad Thontowi, (2005) Hakekat Relegius. Diakses dari http://sumsel.Kemeneg.go.id/ file/dokumen/hakekatreligius 
Alexander,Jannes.(2016).FilsafatKebudayaan Yogjakarta: CV Pustaka pelajar.

Alfan, Muhammad. (2013). Pengantar Filsafat NilaiBandung: CV Pustaka Aetia.

Alpian. (1985). Persepsi Masyarakat Tentang Kebudayaan. Jakarta : PT. Gramedia.

Aminudin. (2009). Apresiasi Karya Seni Tari Daerah Nusantara. Bandung: PT. Puri
Bakhtiar, Amsal. (2004). Filsafat Ilmu. Jakarta: Raja Grafindo.

Djelantik. (1999). Estetika sebuah Pengantar, Bandung: Masyarakat Seni Pertunjukan.

Heriyawati. (2016). Seni Pertunjukan dan Ritual. Yogjakarta: Ombak.

Indrawati Nur. (2007). Makna Filosofi dan Nila-nilai yang Terkandung dalam Tari Klana Raja Gaya Yogyakarta. Yogjakarta: Universitas Negeri Yogyakarta. 